Journal of Health Promotion and Behavior (2018), 3(3): 150-154

https://doi.org/10.26911/thejhpb.2018.03.03.02

\title{
The Effects of Multiple Sexual Partners and Condoms Use on the Incidence of HIV in Men Having Sex with Men
}

\author{
Evi Erlinda Wati, Rahayu Lubis, R. Kintoko Rochadi \\ Masters Program in Public Health, Faculty of Public Health, Universitas Sumatera Utara
}

\begin{abstract}
Background: HIV has become a problem in the international community. Rapid transmission of HIV becomes a threatfor the entire global community in order to prevent an increasingly widespread. One of the factors that causes HIV is unhealthy sexual behavior. This study aimed to determine the effect of changing partners and condom use on HIV incidence in men having sex with Men (MSM) in the Teladan Health Center in Medan.

Subjects and Method: This was case-control study conducted at Teladan Health Center, in May 2018. A sample of 96 study subjects was selected for this study. The dependent variable was the incidence of HIV. The independent variables were multiple sex partners and condom use. HIV status was obtained from medical record. The other variables were measured by questionnaire. The data were analyzed by a multiple logistic regression.

Results: Multiple sexual partners $(\mathrm{OR}=2.93 ; 95 \% \mathrm{CI}=1.25$ to $6.86 ; \mathrm{p}=0.022)$ and absence of condom use $(\mathrm{OR}=2.83 ; 95 \% \mathrm{CI}=1.23$ to $6.52 ; \mathrm{p}=0.024)$ increased the risk of HIV among men having sex with men.

Conclusions: The occurrence of HIV in MSM is probably 2.9 times due changing partner actions and 2.8 times due to the inconsistent condom use.
\end{abstract}

Keywords: HIV, multiple, sexual partners, condom use, men having sex with men

\section{Correspondence:}

Evi Erlinda Wati. Masters Program in Public Health, Faculty of Public Health, Universitas Sumatera Utara. Jl. Universitas No. 21 Kampus USU Medan 20155, Sumatera Utara.

Email: eviritonga74@gmail.com. Mobile: +08126347701

\begin{abstract}
BACKGROUND
Human Immunodeficiency Virus (HIV) is a virus that causes a decrease in immunity / endurance of the human body, where the cells which were attacked are white blood cells. Decreased immunity / endurance will cause a person to be very susceptible to various infectious diseases which can eventually be fatal (Indonesian Ministry of Health, 2016). Infection caused by this virus has a clinical picture that is not specific with a wide spectrum, starting with asymptomatic infection at the initial stage until the symptoms which are very severe in the late stages. The process of incubation of this HIV event is very long, up to the emergence of symptoms of AIDS (Acquired
\end{abstract}

immunodeficiency syndrome) on average 10 years after infection, sometimes it can take much longer (Daili et al, 1997).

HIV-AIDS is not only a problem in Indonesia but has become an international problem because of its very rapid transmission, so that in a relatively short period of time, there is an increase in cases and more widespread in many countries. This situation has had a very alarming impact in all countries due to the rapid spread of HIV-AIDS so that all global societies must be wary. This concern is also very reasonable because vaccines or drugs that are relatively effective have not been found to treat HIV-AIDS, so the condition is increasingly troubling the international 
community (Masriadi, 2014). Based on WHO data in 2016 which explains that the global situation since the outbreak of HIV, it is stated that more than 70 million people have been infected with this virus. HIV continues to be a major issue of international public health, which has so far killed more than 35 million people. Global$\mathrm{ly}$, in 2016, there were 1 million people who died from HIV-related infections and at the end of 2016 an estimated 36.7 million people were infected with HIV.

This HIV epidemic situation is the main trigger due to sexual transmission and injection drug use (Unicef Indonesia, 2012). Estimates and projections for the number of people with HIV / AIDS at $\geq 15$ years in Indonesia in 2016 were 785,821 people with a total of 90,915 new infections and 40,349 deaths (RI Ministry of Health, 2014). Reports on cases from year to year tend to increase, the number of new HIVpositive cases in 2016 was reported to be 41,250 cases. Based on the gender, the comparison of new HIV positive cases in 2016 shows that there are more men than women. HIV positive in men is $63.3 \%$ and women are $36.7 \%$. Whereas AIDS cases were found in men at $67.9 \%$ while in women $31.5 \%$ (Ministry of Health, 2016). The percentage of HIV positive and AIDS cases according to the reported risk factors for 2016 in heterosexuals was 35.5\%, in MSM (Men havingsex with Men) of $26.1 \%$, unknown at $25.6 \%$, others amounting to $11.0 \%$ and IDU $1.9 \%$.

Based on the data from the Health Office of North Sumatra Province until September 2016, it was found that the highest number of HIV sufferers was in Medan amounting to 525 cases, then Deli Serdang amounting 92 cases, Pematang Siantar 40 cases, Asahan 34 cases, Labuhan Batu and North Tapanuli respectively 26 cases, Simalungun 21 cases, Serdang
Bedagai 16 cases, Tebing Tinggi and Batubara each 11 cases, Labuhan Batu Utara 9 cases, Padang-sidimpuan 5 cases and the lowest is Tanjung Balai and Labuhan Batu Selatan each in 1 case (Provincial Health Office, 2017).

The state of the HIV epidemic in Indonesia until the end of 2020 will continue to experience an increase in the prevalence of cases and is still concentrated in the most at risk population groups, including MSM communities. The number of MSM communities is not small, and currently the MSM community tends to increase. They make specific groups. However, the MSM community is often unknown because they do not open themselves up due to fear of getting social sanctions from the community (Demartoto, 2010).

\section{SUBJECTS AND METHOD}

This was a case-control study conducted at Teladan Health Center, in April 2018. A sample of 96 men having sex with men was selected for this study. The dependent variable was HIV. The independent variables were multiple sexual partners and condom use. HIV status was obtained from medical record. The other variables were measured by questionnaire. The data were analyzed by a multiple logistic regression.

\footnotetext{
RESULTS

Table 1 shows the association between of multiple sexual partners and condom use on the incidence of HIV among men having sex with men. Table 1 shows that there was a positive association between multiple sexual partners and HIV incidence in MSM $(\mathrm{OR}=2.93 ; 95 \% \mathrm{CI}=1.25$ to $6.86 ; \mathrm{p}=$ o.022). There was a positive association between absence of condom use and HIV
} 
Journal of Health Promotion and Behavior (2018), 3(3): 150-154

https://doi.org/10.26911/thejhpb.2018.03.03.02

incidence in $\mathrm{MSM}(\mathrm{OR}=2.83 ; 95 \% \mathrm{CI}=1.23$

to $6.52 ; \mathrm{p}=0.024)$.

Table 1. The association between of multiple sexual partners and condom use on the incidence of HIV among men having sex with men

\begin{tabular}{|c|c|c|c|c|c|c|c|}
\hline \multirow{2}{*}{ Independent Variables } & \multicolumn{2}{|c|}{ HIV (+) } & \multicolumn{2}{|c|}{ HIV (-) } & \multirow{2}{*}{$\mathbf{O R}$} & \multirow{2}{*}{$95 \% \mathrm{CI}$} & \multirow{2}{*}{$\mathbf{p}$} \\
\hline & $\mathbf{n}$ & $\%$ & $\mathbf{N}$ & $\%$ & & & \\
\hline Multiple Partners & & & & & \multirow{3}{*}{2.93} & \multirow{3}{*}{$\begin{array}{l}1.25 \text { to } \\
6.86\end{array}$} & \multirow{3}{*}{0.022} \\
\hline sexual partners $\geq 2$ & 25 & $65.8 \%$ & 13 & $34.2 \%$ & & & \\
\hline $\begin{array}{l}1 \text { sexual partner } \\
\text { The Use of Condom }\end{array}$ & 23 & $39.7 \%$ & 35 & $60.3 \%$ & & & \\
\hline Absence & 33 & $61.1 \%$ & 21 & $38.9 \%$ & \multirow{2}{*}{2.83} & 1.23 to & \multirow[b]{2}{*}{0.024} \\
\hline Consistent & 15 & $35.7 \%$ & 27 & $64.3 \%$ & & 6.52 & \\
\hline
\end{tabular}

\section{DISCUSSIONS}

1. The association between multiple sexual partners and the incidence of HIV among MSM

The result of study showed that there was a positive association between multiple sexual partners on the incidence of HIV among MSM. The result of this study was consistent with Sidjabat et al. (2017), which stated that having more than 1 sexual partner was related to the incidence of HIV/AIDS in MSM community in Semarang. The results of the study also stated that MSM who had sexual relations with more than one person would be 2.6 times more likely to suffer from HIV / AIDS. Riyanto (2017) stated that MSM in Semarang which included bisexuals were $\mathbf{2 4 . 7 \%}$ and heterosexuals were $25 \%$.

An MSM has several sex partners and relationship periods that were relatively less than a year. MSM who changed their sexual partners in the last four weeks were six people (Koblin, 2006). The more the number of sexual partners, the more likely the act of having random sex would increase and lead to infections such as HIV (Muchimba et al, 2013). The large number of sexual partners was also affected by the pattern of internet media access to find sexual partners (Horvath, 2008).

Nowadays, everyone's access to social media was so unlimited that the MSM can easily got friends in their community. Thus, it was likely to increase the risk of spreading the virus from one person to another.

2. The association between the absence of condom use and the incidence of HIV among MSM

The result of this study showed that there was a positive relationship between the absence of condom use and the incidence of HIV among MSM. A study by Firdaus and Agustin (2013) stated that there was a relationship between sexual behavior such as inconsistent condom use and multiple partners with HIV incident in MSM. HIV incidence in MSM was increased 5.8 times by unhealthy sexual behavior. A study by Silan et al. (2013) in Delhi reported that the use of condom was still low, which was only $46 \%$.

Indonesia was in the third rank of the largest HIV prevalence rate in the Asia Pacific (UNAIDS, 2013). In Asia, the rate of HIV prevalence among men who have sex with men has reached 18\% (Global Forum, 2012). HIV/AIDS transmission generally occurred due to risky sexual behavior, causing individuals in situations that were vulnerable to infection. The trend of the spread of HIV/AIDS has now begun to shift. If in the previous time the prevalence rate or the spread of new HIV/AIDS infections was more dominated by drug abusers with the use of alternate needles and syringes, now the pattern of 
distribution has shifted through risky sexual behavior (Hutapea, 2011). Regarding the proportion of HIV/AIDS transmission, risky sexual behavior was usually carried out by population groups that were most consistent in practicing sex with multiple partners, especially homosexuals. In addition, an increase in HIV prevalence in MSM communities was also caused by their reluctance to use condoms to avoid the transmission of the virus.

Condoms were the best method to protect people from the transmission of HIV and condoms have great potential to keep the HIV epidemic more extensive as long as it was used consistently (Davis and Weller, 1999). Continuous use of condoms was very important to reduce the incidence of disease among people who have been sexually active, and the promotion of proper and consistent condom use was the foundation of HIV prevention throughout the world.

Changes in the behavior of MSM cannot be done suddenly on a large scale, but it must be carried out in stages by providing realistic and sustainable choices. It was difficult to expect the respondents to not have sexual activity without using the condoms, because as some respondents said, this has become their habit. Conversely, things would be easier if the changes in sexual behavior were carried out by introducing condom use at first. During this time, the respondents were reluctant to use condoms, but with more persuasive steps such reluctance could be eliminated. The process would gradually continue until they reduced the number of partners or even stop the sexual activities with multiple partners. If people realize that safe and healthy sexual behavior can be accepted as a special norm, which applied to the community of respondents, it was expected that there was a kind of strong internal control of individuals in the community..

The HIV-AIDS prevention program would be effective if it was conducted with a commitment between the community and the government. Prevention efforts include providing health education in schools and communities that have multiple sex partners and alternating use of injecting drugs could increase the risk of HIV. Providing information to the public that the only way to be uninfected was by not having sex with multiple partners or only having sex with one person who did not have HIV. Latex condoms must be used correctly in doing vaginal, anal or oral sex. Increasing treatment facilities for drug addicts would reduce HIV transmission. Likewise, the Harm reduction program which encourages syringe users to use the decontamination method and stop using joint needles has proven to be effective.Providing HIV counseling facilities which the identity of the patient was kept confidential or anonymously and provided places for blood tests. It was suggested that every pregnant woman should start the HIV test in early pregnancy as a routine activity of the standard of pregnancy care (Masriadi, 2014).

\section{REFERENCES}

Kemenkes RI (2016). Situasi Penyakit HIV AIDS di Indonesia. Jakarta: Infodatin Kemenkes RI.

Daili SF, Makes WI, Zubier F, Judanarso J (1997). Penyakit Menular Seksual. Jakarta. Balai Penerbit Fakultas Kedokteran Universitas Indonesia.

Masriadi. 2014. Epidemiologi Penyakit Menular. Depok: PT Rajagrafindo Persada.

Unicef Indonesia. 2012. Respon terhadap HIV dan AIDS. Jakarta: Unicef Indonesia. 
Dinas Kesehatan Kota Medan (2017). Data SIHA Kota Medan. Medan. Dinas Kesehatan Kota Medan.

Koblin B (2006). Risk Factors for HIV Infection among Men Who Have Sex With Men. Lippincott Williams Wilkins AIDS. 20: 731-739.

Riyanto, Puguh (2017). Knowledge, Attitude, Behavior Men Who Have Sex With Men Related To HIV/AIDS In Semarang Indonesia. Journal Of AIDS And Clinical Research, 8(5): 1-2. Muchimba M, Haberstick BC, Corley RP, McQueen M (2013). Frequency of Alcohol Use in Adolescence as a Marker for Subsequent Sexual Risk Behavior in Adulthood. J Adolesc Heal, 53(2): 215-221.

Firdaus A, Agustin H (2013). Faktor Risiko Kejadian HIV pada Komunitas LSL (Lelaki Seks dengan Lelaki) Mitra Yayasan Lantera Minangkabau Suma- tera Barat. Jurnal Kesehatan Komunitas, 2(2): 94-99.

Silan V, Kant S, Haldar P, Goswami K, Rai SK, Misra P (2013). HIV Risk Behavior Among Men Who Have Sex With Men. North American Journal Of Medical Science, 5(9): 515-522.

UNAIDS (2013). Report on the Global HIV/AIDS Epidemic: Executive summary. Diakses di www.unaids.org

Hutapea R (2011). AIDS, PMS dan Perkosaan. Jakarta: Rineka Cipta.

Davis KR, Weller SC (1999). The Effectiveness of Condoms in Reducing Heterosexual Transmission of HIV. Family Planning Perspectives. 31(6): 272279.

Masriadi (2014). Epidemiologi Penyakit Menular. Depok: PT Rajagrafindo Persada. 